\title{
INTERNET FINANCIAL REPORTING, PENGUNGKAPAN INFORMASI WEBSITE, LUAS LINGKUP PELAPORAN INTERNET, DAN NILAI PERUSAHAAN
}

\author{
I Made Narsa \\ narsa_ua@yahoo.com \\ Fitri Fenti Pratiwi \\ Departemen Akuntansi Fakultas Ekonomi dan Bisnis Universitas Airlangga
}

\begin{abstract}
Objectives of this research are to examine, firstly, is there any difference of firm value between corporations which apply Internet Financial Reporting (IFR) and which don't. Secondly, is there any effect of degree of website information disclosure (TPIW) and Broad scope of internet reporting (LPI) to firm value (Q). To test the robustness of this research, this research use firm size (SIZE) and profitability (ROA) as control variables. Samples of this research were 184 non financial corporations registered in Indonesia Stock Exchange during 2012. The result shows that the companies that do IFR proven have a higher firm value than companies that don't. This difference is statistically significant. This research also document that TPIW, LPI, and ROA have a significant positive effect on firm value, but SIZE has negative effect. This result implies that company which conduct IFR, do more website information disclosure, and has a broad scope of internet reporting could be a good signal for investor so that it increases the firm value.
\end{abstract}

Keywords: internet financial reporting, firm value, website information disclosure, profitability, size.

\begin{abstract}
ABSTRAK
Penelitian ini bertujuan untuk menguji, (1) apakah ada perbedaan nilai perusahaan antara perusahaan yang menerapkan Internet Financial Reporting (IFR) dan perusahaan yang tidak menerapkan. (2) apakah ada pengaruh tingkat pengungkapan informasi website (TPIW) dan luas lingkup pengungkapan IFR (LPI) terhadap nilai perusahaan (Q). Untuk menguji kerobasan hasil, penelitian ini menggunakan variabel kontrol yaitu ukuran perusahaan (SIZE) dan profitabilitas (ROA). Jumlah sampel yang diteliti sebanyak 184 perusahaan non keuangan yang terdaftar di BEI selama tahun 2012. Hasil penelitian menunjukkan bahwa perusahaan yang melakukan IFR terbukti memiliki nilai perusahaan yang lebih tinggi dibandingkan dengan perusahaan yang tidak melakukan. Perbedaan ini secara statistik signifikan. Penelitian ini juga mendokumentasi bahwa TPIW, LPI, dan ROA berpengaruh positif terhadap nilai perusahaan, sementara SIZE berpengaruh negatif. Temuan penelitian ini mengimplikasi bahwa perusahaan yang melakukan IFR, melakukan pengungkapan informasi lewat website yang semakin banyak, dan memiliki lingkup pengungkapan informasi website yang luas dapat menjadi sinyal positif bagi investor sehingga dapat meningkatkan nilai perusahaan.
\end{abstract}

Kata kunci: internet financial reporting, nilai perusahaan, pengungkapan informasi website, profitabilitas, ukuran.

\section{PENDAHULUAN}

Penggunaan internet, dalam dunia yang semakin global, sudah menjadi suatu kebutuhan yang sangat signifikan pada segala aspek kehidupan. Menurut Ash- baugh et al. (1999) dan Debreceny et al. (2002), internet menjadi media penyampaian informasi yang penting karena mempunyai keunggulan seperti mudah menyebar (pervasiveness), tidak mengenal batas 
(borderless-ness), real-time, berbiaya rendah (low cost), dan mempunyai interaksi yang tinggi (high interaction) serta diintegrasi dengan teks, angka, gambar, animasi, video, dan suara. Internet menjadi alternatif media pelaporan yang utama, sehingga informasi tentang kinerja perusahaan dapat dijangkau secara global oleh stakeholder. Penggunaan internet telah menjadi salah satu alat dan media yang mendukung keterbukaan dan transparansi pelaporan informasi karena dapat mengurangi tingkat asimetri informasi, sehingga dapat mempercepat laju pertumbuhan perusahaan.

Stakeholder membutuhkan sistem pelaporan yang fleksibel yang akan memungkinkan mereka memperoleh informasi dengan cara yang lebih mudah. Internet menawarkan suatu bentuk unik pengungkapan yang menjadi media bagi perusahaan dalam menyediakan informasi kepada masyarakat luas sesegera mungkin (Abdelsalam et al., 2007). Atas dasar itulah muncul suatu media tambahan dalam penyajian laporan keuangan melalui internet yang lazim disebut Internet Financial Reporting (IFR). Menurut Lai et al. (2010) secara sederhana, IFR dapat didefinisi sebagai pencantuman informasi keuangan perusahaan melalui internet pada website resmi perusahaan dan mendukung perpindahan periode paper-based reporting system ke paper-less reporting system.

IFR mempunyai dua elemen yang dapat membantu perusahaan untuk mengetahui seberapa luas kinerja pelaporannya, yaitu tingkat pengungkapan informasi website dan lingkup pelaporan internet. Sedangkan, esensi dari IFR adalah derajat atau kuantitas pengungkapan (Ashbaugh et al., 1999). Semakin tinggi tingkat pengungkapan informasi dalam kuantitas atau transparansi, maka semakin besar dampak dari pengungkapan tersebut terhadap keputusan investor.

Tujuan jangka panjang perusahaan adalah meningkatkan nilai perusahaan melalui peningkatan kemakmuran pemilik atau para pemegang saham. Jika perusaha- an berjalan lancar, maka nilai saham perusahaan akan meningkat. Secara teoretis, apabila nilai sahamnya tinggi bisa dikatakan nilai perusahaannya juga baik. Nilai perusahaan sangat penting karena nilai perusahaan yang tinggi akan diikuti oleh tingginya kemakmuran pemegang saham. Semakin tinggi harga saham semakin tinggi nilai perusahaan. Nilai perusahaan yang tinggi menjadi keinginan para pemilik perusahaan, karena dengan nilai perusahaan yang tinggi menunjukkan kemakmuran pemegang saham juga tinggi.

Hasil penelitan-penelitian sebelumnya mengenai IFR tidak konsisten (Afifurrahman dan Hapsoro, 2005; Aly et al., 2010; Craven dan Marston, 1999; Lestari dan Chariri, 2005). Oleh karena itu diperlukan adanya suatu penelitian lanjutan guna menguji model teoretis dari model tersebut secara empiris. Penelitian ini bertujuan untuk menguji (1) Apakah terdapat perbedaan nilai perusahaan antara perusahaan yang menerapkan Internet Financial Reporting dengan perusahaan yang tidak menerapkan; (2) Apakah tingkat pengungkapan informasi website serta lingkup pelaporan internet pada perusahaan yang menerapkan Internet Financial Reporting berpengaruh terhadap nilai perusahaan.

\section{TINJAUAN TEORETIS \\ Teori Keagenan}

Dalton et al. (2007) mengungkapkan bahwa teori keagenan menyebabkan perbedaan kepentingan dan kurangnya keselarasan tujuan, preferensi, dan tindakan antara pihak prinsipal dan agen. Konflik kepentingan inilah yang kemudian disebut dengan masalah keagenan (agency problem). Ketidakseimbangan pemilikan informasi antara pihak manajemen sebagai penyedia informasi dan pemegang saham (shareholder) sebagai pengguna informasi merupakan masalah inti dari asimetri informasi. Untuk mengatasi hal ini, pemilik mengharuskan pihak manajemen untuk menyiapkan laporan keuangan standar agar dapat 
memonitor dan mengendalikan tindakan manajemen dan sebagai wujud pertanggungjawaban. Teori keagenan menjelaskan bahwa agen akan berusaha memenuhi seluruh keinginan prinsipal. Menurut teori ini, asimetri informasi antara manajemen dan pemegang saham yang tinggi akan menyebabkan kebutuhan informasi oleh pemegang saham sebagai prisipal yang lebih banyak dan dari sumber dan media yang beragam.

\section{Teori Sinyal}

Teori sinyal merupakan teori yang menjelaskan bahwa perusahaan harus memanfaatkan informasi laporan keuangan untuk memberi sinyal positif maupun negatif kepada pihak eksternal. Dorongan untuk mengungkap informasi ini muncul sebagai salah satu cara untuk mengatasi asimetri informasi antara pihak internal perusahaan dengan pihak eksternal karena perusahaan memiliki informasi lebih banyak mengenai apa yang sudah dilakukan perusahaan dan prospek perusahaan dari pada pihak eksternal (Wolk et al., 2001). Berdasarkan teori sinyal, perusahaan akan selalu mencoba untuk memberi tingkat pengungkapan yang sama dengan perusahaan lain dalam industri yang sama karena jika tingkat pengungkapan informasi perusahaan tidak sama dengan tingkat pengungkapan perusahaan lain akan menyebabkan stakeholder mencurigai pihak manajemen perusahaan menyembunyikan informasi yang kurang baik (Cravendan Marston, 1999). Perkembangan jaman yang diiringi dengan berkembangnya teknologi semakin meningkatkan permintaan pemilik atau investor perusahaan akan kecepatan dan sistem pelaporan yang fleksibel sehingga informasi dapat diakses dengan lebih mudah (Abdelsalam et al., 2007).

Di samping itu, teori sinyal digunakan sebagai dasar untuk menguji mengenai information content (kandungan informasi) dalam peristiwa pengungkapan Internet Financial Reporting (IFR). Teori sinyal mengemukakan bagaimana cara perusahaan memberi sinyal berupa informasi kepada investor. Sinyal tersebut diantaranya berupa informasi tentang kinerja perusahaan, baik informasi keuangan maupun non keuangan dalam pengungkapan IFR, sehingga sinyal tersebut dapat mempengaruhi reaksi investor yang terefleksi dalam perubahan harga saham, sebagaimana yang ditunjukkan melalui informasi abnormal return saham perusahaan.

Keberadaan reaksi investor terhadap pengungkapan Internet Financial Reporting (IFR) juga dipengaruhi oleh tingkat informasi dan ruang lingkup pengungkapan Internet Financial Reporting (IFR). Tingkat informasi dan ruang lingkup pengungkapan IFR merupakan faktor penting dari Internet Financial Reporting (IFR). Semakin tinggi tingkat kuantitas pengungkapan informasi, maka semakin besar dampak dari pengungkapan IFR pada keputusan investasi investor. Di samping itu, adanya tingkat pengungkapan IFR yang tinggi memiliki kecenderungan mempunyai nilai abnormal return yang lebih besar dan selanjutnya diikuti oleh perubahan harga saham yang bergerak lebih cepat (Lai et al., 2010).

\section{Teori Stakeholder}

Teori Stakeholder mengasumsikan bahwa perusahaan tidak hanya bertanggung jawab kepada investor saja, akan tetapi juga harus bertanggung jawab kepada berbagai kelompok dalam masyarakat yang memiliki hubungan dengan perusahaan. Kondisi ini terbentuk karena perilaku dan keputusan yang dibuat oleh perusahaan akan memiliki pengaruh terhadap kesejahteraan masyarakat (Masykur, 2013).

Fassin (2009) menyatakan bahwa hubungan antar pihak-pihak yang berkepentingan dengan perusahaan (stakeholder) pada dasarnya dapat dikelompokkan menjadi 3 (tiga) kelompok yaitu stakeholder (yaitu kelompok yang memiliki hak atas perusahaan dan selanjutnya perusahaan memiliki tanggung jawab terhadap 
kelompok tersebut), stakewatcher (yaitu kelompok yang tidak memiliki hak atas perusahaan namun mereka berkepentingan untuk memihak kepentingan dari stakeholder secara langsung, dan seringkali dilakukan dengan berbagai macam cara seperti berbagai bentuk proses maupun menjadi penengah, namun biasanya perusahaan sulit untuk mempengaruhi mereka, misalnya pressure group), dan stakekeeper (yaitu kelompok yang meskipun tidak memiliki hak atas perusahaan namun kelompok tersebut memiliki pengaruh dan kekuasaan yang kuat untuk mempengaruhi perusahaan melalui berbagai peraturan-peraturan yang dibuat maupun berbagai hambatan-hambatan yang dihadapi).

\section{Internet Financial Reporting (IFR)}

Pelaporan keuangan yang diungkap melalui internet adalah informasi keuangan yang disampaikan oleh pihak manajemen perusahaan kepada pihak pemangku kepentingan (stakeholder), khususnya investor. Informasi yang disampaikan kepada pasar tersebut dapat mempengaruhi reaksi pasar atau reaksi investor. Selanjutnya investor akan merespon informasi tersebut sebagai sebuah sinyal terhadap adanya peristiwa (event) tertentu. Respon para investor terhadap pengungkapan pelaporan keuangan melalui internet dapat berupa respon positif atau respon negatif. Investor akan memberi sebuah respon positif jika informasi yang dipublikasi merupakan informasi baik (goodnews) dan sebaliknya investor akan memberi sebuah respon negatif jika informasi yang dipublikasi merupakan informasi badnews (Mooduto, 2013).

IFR adalah pencantuman informasi keuangan perusahaan melalui internet atau website resmi perusahaan (Lai et al., 2010). Pengungkapan melalui website ini dimaksudkan agar informasi dapat tersedia bagi siapapun, dimanapun, dan kapanpun. IFR disebut sebagai pengungkapan sukarela (voluntary disclosure), hal ini bukan dilihat dari isinya, tetapi dari media atau alat yang digunakan (Barac, 2004). Keuntungan pe- nerapan IFR menurut Almilia (2009) antara lain adalah, pertama penggunaan internet sebagai media penyampaian laporan keuangan merupakan suatu penghematan bagi perusahaan karena tidak perlu lagi mencetak laporan keuangan menggunakan kertas. Proses pendistribusian laporan keuangan kepada pihak yang berkepentingan juga lebih efisien dan real-time, karena pihak yang ingin melihat laporan keuangan perusahaan dapat langsung memperolehnya melalui internet. Kedua, kemudahan dalam mengakses informasi terkini, yang mana setiap investor dapat mengakses informasi laporan keuangan dengan cepat dan mudah dimanapun dan kapanpun mereka mau. Ketiga menyediakan media komunikasi dua arah antara manajemen perusahaan dan pengunjung website. Beberapa perusahaan bahkan telah mengizinkan pengunjung website mereka untuk mendaftar sebagai anggota agar dapat dikirimi email tentang berita-berita mengenai hal-hal terbaru tentang perusahaan.

Ashbaugh et al. (1999) mengungkapkan elemen penting IFR adalah derajat atau kuantitas pengungkapan. Semakin tinggi tingkat pengungkapan informasi dan transparansi sebuah perusahaan, semakin besar dampak dari pengungkapan tersebut terhadap keputusan investor. IFR juga memiliki kelemahan, yaitu informasi yang diungkap mungkin kurang akurat apabila perusahaan hanya mengutamakan kecepatan dalam menyampaikan laporan keuangan daripada keakuratannya. Selain itu, perusahaan kompetitor akan lebih mudah mengetahui informasi laporan keuangan perusahaan, sehingga sangat berisiko dalam perebutan pangsa pasar (Damayanti dan Supatmi, 2012).

\section{Tingkat Pengungkapan Informasi Website}

Tingkat pengungkapan informasi website pertama kali digunakan oleh Ettredge et al. (2002) untuk mengukur tipe pelaporan informasi yang ada dalam website perusahaan dengan menggunakan item-item 
pengukurannya, yaitu berita terkini, informasi keuangan, dan informasi saham. Lai et al. (2010) kembali mengadaptasi tingkat pengungkapan informasi website ini dan memotivasinya dengan menambahkan dua tipe pelaporan informasi website perusahaan yang menerapkan IFR, yaitu profil dasar perusahaan dan item operasional. Tingkat pelaporan informasi website ini berguna untuk mengetahu kuantitas informasi yang ada dalam website perusahaan. Semakin tinggi tingkat pengungkapan informasi website perusahaan, maka semakin besar dampak dari pengungkapan tersebut terhadap keputusan investor.

Pasar akan bereaksi apabila terdapat informasi yang relevan memasuki pasar. Internet Financial Reporting (IFR) merupakan pengungkapan yang bersifat voluntary (sukarela) yang berisi informasi, baik berupa informasi keuangan maupun nonkeuangan. Pengungkapan IFR ini akan menjadi pendorong (stimulus) bagi investor untuk mengambil sikap dalam pengambilan keputusan investasi yang selanjutnya akan mampu mengubah keseimbangan pasar. Kondisi tersebut pada akhirnya akan mempengaruhi transaksi perdagangan saham perusahaan, misalnya volume perdagangan saham, frekuensi perdagangan saham, dan harga saham.

Di samping itu, pengungkapan IFR akan mampu mempercepat akses investor terhadap informasi yang diberikan. Kecepatan informasi yang diterima pihak investor melalui IFR akan memperpendek delay aksesibilitas informasi, sehingga harga saham pada perusahaan yang menerapkan IFR akan bersifat responsif. Dengan demikian maka dapat disimpulkan bahwa perubahan harga saham perusahaan dipengaruhi oleh baik kuantitas maupun kualitas informasi yang diungkap oleh perusahaan. Penelitian yang dilakukan Easley et al. (2002) menunjukkan bahwa kuantitas dan kualitas informasi perusahaan akan mampu mempengaruhi harga saham dalam keseimbangan. Di samping itu, penelitian juga menyimpulkan bahwa investor yang memperoleh informasi lebih relevan akan mampu meningkatkan return yang lebih tinggi pada investasi yang dilakukan.

\section{Lingkup Pelaporan Internet}

Lingkup pelaporan internet dikembangkan oleh Ashbaugh et al. (1999) dan Craven dan Marston (1999) dan digunakan kembali oleh Lai et al. (2010) untuk meneliti penerapan IFR secara lebih luas. Tujuan dari penggunaan lingkup pelaporan internet adalah sebagai informasi tambahan dalam website pusat yang dimiliki perusahaan. Lingkup pelaporan internet digunakan untuk melihat dan mengukur struktur website pusat yang dimiliki perusahaan terhubung dengan website lain baik yang ada di dalam perusahaan ataupun di luar perusahaan. Item-item yang ada dalam lingkup pelaporan internet adalah website bursa saham, website anak perusahaan dan divisi utama, website unit bisnis strategis, dan website milik perusahaan hulu seperti pemasok dan produsen, serta perusahaan hilir seperti distributor, pengecer, dan konsumen.

\section{Nilai Perusahaan}

Tujuan utama perusahaan menurut theory of the firm adalah memaksimalkan kemakmuran atau nilai perusahaan (Salvatore, 2005). Memaksimalkan nilai perusahaan merupakan salah satu upaya perusahaan untuk mencapai tujuan utama perusahaan melalui peningkatan kemakmuran para pemegang saham. Nilai perusahaan menggambarkan seberapa baik manajemen mengelola perusahaan

Dalam penelitian ini, nilai perusahaan didefinisi menggunakan konsep nilai pasar. Adanya informasi mengenai peluang investasi melalui harga saham perusahaan akan memberi sinyal positif tentang pertumbuhan perusahaan di masa yang akan datang sehingga dapat meningkatkan nilai perusahaan (Fama, 1978). Semakin tinggi harga saham, semakin tinggi tingkat kemakmuran pemegang saham dan membuat nilai perusahaan juga tinggi. Nilai perusahaan 
yang tinggi akan membuat pasar menjadi percaya tidak hanya pada kinerja perusahaan saat ini, namun juga pada prospek perusahaan di masa depan. Umumnya, untuk mencapai tujuan tersebut, para pemodal menyerahkan pengelolaan perusahaan kepada para profesional. Dalam hal ini, para profesional diposisikan sebagai manajer ataupun dianggap komisaris (Nurlela dan Islahuddin, 2008).

Tobin's $Q$ dinilai dapat memberi informasi yang paling baik karena memasukkan seluruh aset dan liabilitas perusahaan (Sukamulja dan Sukmawati, 2004). Semakin besar nilai Tobin's $Q$, semakin baik prospek pertumbuhan perusahaan di masa depan. Hal ini disebabkan oleh semakin besarnya nilai pasar aset perusahaan yang dibandingkan dengan nilai buku aset perusahaan, dan berarti semakin besar pula kerelaan investor untuk mengeluarkan pengorbanan yang lebih besar demi memiliki perusahaan tersebut (Sukamulja dan Sukmawati, 2004).

\section{Ukuran Perusahaan}

Ukuran perusahaan adalah ukuran besar kecilnya suatu perusahaan. Setiap perusahaan memiliki agency cost yang berbeda-beda. Menurut Oyelere dan Karuppu (2012), agency cost tersebut berupa biaya penyebarluasan laporan keungan, termasuk biaya cetak dan biaya pengiriman laporan keuangan kepada pihak-pihak yang dituju oleh perusahaan. Perusahaan besar (big) memiliki agency cost yang lebih tinggi daripada perusahaan kecil. Hal ini dikarenakan perusahaan besar memiliki kewajiban yang lebih besar dalam menyampaikan laporan keuangan secara lengkap dan cepat kepada shareholder sebagai wujud pertanggungjawaban manajemen kepada para shareholder-nya.

\section{Profitabilitas Perusahaan}

Profitabilitas merupakan suatu aspek penting yang menjadi acuan bagi investor atau pemilik perusahaan untuk menilai kinerja manajemen dalam mengelola atau menjalankan suatu perusahaan. Perusahaan-perusahaan dengan tingkat profitabilitas yang baik akan cenderung memiliki dorong an yang lebih kuat untuk menyebarluaskan informasi mengenai perusahaan, terutama informasi keuangan karena profitabilitas yang tinggi merupakan salah satu indikasi bahwa perusahaan tersebut telah melakukan dan mencapai kinerja dengan baik. Hal tersebut juga bertujuan untuk meningkatkan kepercayaan investor dalam melakukan berbagai keputusan investasi yang lebih baik pada perusahaan tersebut.

Disisi lain, perusahaan dengan kinerja perusahaan yang buruk akan lebih menolak untuk mengungkap laporan keuangannya kepada para pihak yang berkepentingan dan lebih memilih untuk membatasi akses informasi akuntansinya (Srimindarti, 2008).

\section{Internet Financial Reporting dan Nilai Perusahaan}

Sebuah informasi dapat menjadi pemicu bagi pembuat keputusan untuk mengevaluasi kembali keputusannya dan kemudian dari hal tersebut mereka mengambil sebuah tindakan yang dianggap tepat. Ketika perusahaan menyediakan informasi dan berkomunikasi dengan pasarnya menggunakan tingkat transparansi yang beragam akan memberi konsekuensi berupa akumulasi reputasi perusahaan yang secara siginifikan berkontribusi pada nilai perusahaan di masa sekarang maupun masa depan perusahaan. Salah satu cara efektif yang dapat dilakukan perusahaan untuk menyampaikan informasi di masa global ini adalah dengan IFR karena memberi kemudahan bagi stakeholder untuk mengakses informasi perusahaan secara cepat, akurat, dan fleksibel. Informasi yang diungkap perusahaan memiliki pengaruh terhadap nilai perusahaan. Kunggulan dari penggunaan IFR memicu perusahaan untuk mengungkap informasi lebih banyak, transparan, dan relevan. Berdasarkan perjelasan 
tersebut hipotesis pertama dapat dirumuskan sebagai berikut:

$\mathrm{H}_{1}$ : Nilai perusahaan yang menerapkan Internet Financial Reporting lebih tinggi daripada nilai perusahaan yang tidak menerapkan Internet Financial Reporting.

\section{Tingkat Pengungkapan Informasi Website, Lingkup Pelaporan Internet, dan Nilai Perusahaan}

Debreceny et al. (dalam Prasetya dan Irwandi, 2012) menyatakan bahwa penggunaan internet memiliki beberapa keuntungan yaitu pelaporan keuangan menjadi lebih cepat dan mudah sehingga dapat diakses oleh siapa pun, kapan pun dan dimana pun. Di samping itu, keuntungan internet adalah mempercepat penyajian informasi keuangan serta menghemat biaya karena perusahaan tidak perlu untuk mengeluarkan biaya mencetak laporan keuangan maupun biaya untuk distribusi laporan keuangan yang tidak berada dalam satu geografis, sehingga penyampaian informasi dapat dilakukan dengan lebih cepat dan dapat meningkatkan frekuensi penyajian informasi keuangan.

Di Indonesia penelitian mengenai Internet Financial Reporting telah dilakukan oleh Lestari dan Chariri (2005) yang meneliti faktor-faktor yang memengaruhi praktik pelaporan keuangan melalui internet dalam website perusahaan di Indonesia. Populasi penelitian ini adalah perusahaanperusahaan yang terdaftar di Bursa Efek Jakarta pada tahun 2005, kecuali perusahaan-perusahaan finansial. Variabel independen yang digunakan adalah ukuran perusahaan, likuiditas, jenis industri, leverage, reputasi auditor, dan umur listing perusahaan. Sedangkan variabel dependen yang digunakan adalah pelaporan keuangan melalui internet dalam website perusahaan (IFR). Hasil penelitian menunjukkan bahwa faktor-faktor seperti ukuran perusahaan, likuiditas, leverage, reputasi auditor, dan umur listing perusahaan ber- pengaruh terhadap praktik IFR. Akan tetapi, faktor-faktor yang lain seperti profitabilitas dan jenis industri tidak memengaruhi pilihan perusahaan untuk menggunakan internet sebagai media pelaporan keuangan melalui website yang dimiliki perusahaan.

IFR merupakan sebuah jalan keluar yang efektif untuk mengurangi permasalahan asimetri informasi. Terdapat dua elemen penting dalam IFR yang digunakan oleh Lai et al. (2010) untuk melihat tingkat transparansi informasi yang dilakukan oleh perusahaan yaitu tingkat pengungkapan informasi website dan lingkup pelaporan internet. Semakin tinggi tingkat pengungkapan dan lingkup pelaporan dalam kuantitas transparansi, semakin besar dampak dari pengungkapan tersebut pada pro ses pengambilan keputusan investor. Berkurangnya asimetri informasi pada perusahaan dapat menyebabkan naiknya nilai perusahaan secara signifikan. Dengan demikian, dapat disimpukan apabila perusahaan mempunyai derajat transparansi yang tinggi melalui tingkat pelaporan informasi website dan lingkup pelaporan internet, dan akan memberi manfaat pada tingginya nilai perusahaan karena berkurangnya asimetri informasi dan ketidakpastian prospek perusahaan di masa depan. Hipotesis kedua dapat dirumuskan sebagai berikut ini:

$\mathrm{H}_{2 \mathrm{a}}$ : Tingkat pengungkapan informasi website pada perusahan yang menerapkan Internet Financial Reporting berpengaruh positif terhadap nilai perusahaan.

$\mathrm{H}_{2 b}$ : Lingkup pelaporan internet pada perusahan yang menerapkan Internet Financial Reporting berpengaruh positif terhadap nilai perusahaan.

\section{METODE PENELITIAN}

Penelitian ini dilakukan dengan pendekatan kuantitatif. Penelitian kuantitatif adalah suatu proses menemukan pengetahuan yang menggunakan data berupa angka sebagai alat yang dapat digeneralisasi untuk membuktikan hipotesis. Data yang 
digunakan dalam penelitian ini adalah data sekunder, yaitu sumber yang tidak langsung memberi data kepada pengumpul data, misalnya melalui orang lain atau lewat dokumen (Sugiyono, 2008).

Populasi penelitian ini yaitu perusahaan non finansial yang terdaftar di Indonesian Stock Exchange (IDX) pada tahun 2012 dengan kriteria yaitu data keuangan perusahaan lengkap dan disajikan dalam mata uang rupiah. Kemudian, seluruh perusahaan yang memenuhi kriteria tersebut dijadikan sebagai sampel dalam penelitian ini (sampel jenuh). Pada penelitian ini sampel dibedakan menjadi dua kelompok yaitu perusahaan yang menerapkan IFR dan perusahaan yang tidak menerapkan IFR. Data target populasi dan sampel disajikan pada tabel 1 berikut ini.

Tabel 1

Target Populasi dan Sampel

\begin{tabular}{lcc}
\hline \multicolumn{1}{c}{ Kriteria } & Jumlah & Total \\
\hline $\begin{array}{l}\text { Perusahaan yang menerapkan Internet Financial Reporting } \\
\begin{array}{l}\text { Perusahaan yang mempunyai website tetapi tidak menerapkan } \\
\text { Internet Financial Reporting }\end{array}\end{array}$ & 41 & 92 \\
$\begin{array}{l}\text { Perusahaan yang mempunyai website, tetapi tidak update atau } \\
\text { dalam gangguan }\end{array}$ & 10 & \\
$\begin{array}{l}\text { Perusahaan yang tidak mempunyai website } \\
\text { Perusahaan yang tidak menerapkan Internet Financial } \\
\text { Reporting }\end{array}$ & 41 & 92 \\
\hline Total Sampel & & 184 \\
\hline
\end{tabular}

\section{Definisi Operasional Variabel}

Variabel-variabel yang diteliti dalam penelitian ini adalah: Internet Financial Reporting (IFR); Tingkat Pengungkapan Informasi Website (TPIW); Lingkup Pelaporan Internet (LPI); dan sebagai variabel kontrol adalah Ukuran Perusahaan (SIZE); Profitabilitas (ROA), dan Nilai Perusahaan (Q). Nilai perusahaan merupakan kondisi tertentu yang telah dicapai oleh suatu perusahaan sebagai gambaran dari kepercayaan masyarakat terhadap perusahaan setelah melalui suatu proses kegiatan selama beberapa tahun, yaitu sejak perusahaan tersebut didirikan sampai dengan saat ini.

Meningkatnya nilai perusahaan tersebut adalah merupakan sebuah prestasi yang sesuai dengan keinginan para pemiliknya, karena dengan meningkatnya nilai perusahaan, maka kesejahteraan para pemilik juga akan meningkat. Dalam peneliti- an ini nilai perusahaan diukur dengan menggunakan ukuran Tobin's Q.

$\mathrm{Q}=\frac{M V S+D}{T A}$

Keterangan:

Q : Nilai Perusahaan

MVS : Market Value of all outstanding Shares yang diperoleh dari perkalian jumlah saham yang beredar dengan harga penutupan saham

D : Nilai buku dari total hutang

TA : Nilai buku dari total aset

Apabila nilai Tobin's Q lebih dari satu, maka mengindikasikan bahwa perusahaan memiliki nilai pasar yang melebihi harga penggantian (price replacement) atas aset. Sebaliknya, jika nilai Tobin's Q kurang dari satu, menunjukkan bahwa perusahaan telah kehilangan nilainya karena adanya ketidak mampuan manajemen untuk membayar modal pemilik (owners capital) dengan rasio 
yang lebih besar dari rasio minimum daya tarik bisnis.

Internet Financial Reporting adalah pencantuman informasi keuangan perusahaan melalui internet atau website resmi perusahaan. Dalam penelitian ini, IFR dinyatakan sebagai variabel dummy. Cara pemberian kode dummy umumnya menggunakan kategori yang dinyatakan dengan angka 1 (included group) dan 0 (excluded group) atau dengan kata lain 1 untuk perusahaan yang menerapkan IFR dan 0 untuk lainnya.

Tingkat Pengungkapan Informasi Website adalah tipe laporan termasuk cakupan jenis pelaporan informasi yang ada dalam website perusahaan dengan menggunakan item-item pengukurannya, yaitu berita terkini, informasi keuangan, dan informasi saham. Pengukuran pada variabel ini menggunakan skala poin 4. Profil dasar perusahaan diberi nilai 1 poin. Nilai 2 poin diberikan untuk laporan keuangan kuartal dan laporan setengah tahunan atau tahunan sederhana. Satu set lengkap laporan keuangan (kuartalan, setengah tahun atau tahunan) dan laporan tahunan direksi diberi poin 3. Pelaporan rinci tahunan direksi termasuk strategi bisnis perusahaan dan anak perusahaan divisi utama dan tujuan serta rencana bisnis diberikan 4 poin.

Lingkup pelaporan internet adalah struktur website pusat yang dimiliki perusahaan terhubung dengan website lain baik yang ada di dalam perusahaan ataupun di luar perusahaan. Item-item yang ada dalam lingkup pelaporan internet adalah website bursa saham, website anak perusahaan dan divisi utama, website unit bisnis strategis, dan website milik perusahaan hulu seperti pemasok dan produsen, serta perusahaan hilir seperti distributor, pengecer, dan konsumen. Variabel lingkup pelaporan internet ini diukur dengan menggunakan variabel dummy yaitu nilai 1 untuk perusahaan yang mempunyai item pengungkapan internet dan 0 untuk perusahaan yang lainnya yang tidak mempunyai item pengungkapan internet.
Ukuran Perusahaan, diukur dengan logaritma natural dari total aset perusahaan yang diperoleh dari laporan keuangan perusahaan, yaitu: Ukuran perusahaan (size) $=\ln$ (Total Aset). Profitabilitas Perusahaan diukur menggunakan ROA (Return On Asset) yang diperoleh dari laba bersih setelah pajak dibagi dengan total aset. Rumus Return On Asset dapat dijabarkan menjadi sebagai berkut:

ROA $=\frac{\text { Net Income }}{\text { Total Aset }}$

Keterangan:

Net Income = Laba bersih setelah pajak

Total Aset = Nilai buku total aset perusahaan

\section{Model Empiris}

Pengujian pengaruh variabel-variabel independen terhadap variabel dependen dalam penelitian ini menggunakan analisis regresi linier berganda (multiple regression) yang merupakan analisis untuk mengekspresikan hubungan linier antara dua variabel atau lebih. Berikut ini adalah model empiris penelitian tersebut:

$$
\begin{aligned}
\mathrm{Q}= & a+\beta_{1} \mathrm{TPIW}+\beta_{2} \mathrm{LPI}+\beta_{3} \mathrm{SIZE}+ \\
& \beta_{4} \mathrm{ROA}+\mathrm{e}
\end{aligned}
$$

Keterangan:

$\begin{array}{ll}\mathrm{Q}= & \text { Nilai perusahaan pada per- } \\ & \text { usahaan yang menerapkan } \\ & \text { IFR } \\ = & \text { Konstanta } \\ \mathrm{a} & = \\ \beta_{1}, \beta_{2}, \beta_{3}, \beta_{4}= & \text { Koefisien regresi } \\ \mathrm{TPIW} & \text { Tingkat pengungkapan infor- } \\ & \text { masi website } \\ \mathrm{LPI} & \text { Lingkup pelaporan internet } \\ \mathrm{SIZE} & \text { Ukuran perusahaan yang di- } \\ & \text { ukur dengan total aset } \\ \mathrm{ROA} & \text { Profitabilitas yang diukur } \\ & \text { menggunakan Return on } \\ & \text { Asset } \\ = & \text { Error term, yaitu tingkat ke- } \\ & \text { salahan penduga dalam pe- } \\ & \text { nelitian }\end{array}$




\section{ANALISIS DAN PEMBAHASAN \\ Deskripsi Hasil Penelitian}

Sebelum pengujian hipotesis, perlu dideskripsi karakteristik data penelitian dengan menggunakan analisis deskriptif untuk memberi gambaran mengenai variabelvariabel yang diteliti. Uji normalitas data juga dilakukan untuk mendeteksi distribusi data penelitian yang digunakan. Apabila data penelitian terdistribusi normal, maka uji beda akan dilakukan dengan Uji $t$ Sampel Independen, namun apabila sebaliknya data penelitian tidak terdistribusi normal, maka penelitian ini akan menggunakan Uji Mann Whitney. Tabel 2 berikut menyajikan statistik deskriptif variabelvariabel penelitian.

Tabel 2

Statistik Deskriptif Internet Financial Reporting dan Nilai Perusahaan

\begin{tabular}{cccccc}
\hline \hline & N & Minimum & Maximum & Mean & Standard Dev. \\
\hline IFR & 184 & 0,00 & 1,00 & 0,50 & 0,50 \\
$\mathrm{Q}$ & 184 & 0,13 & 14,04 & 2,04 & 2,06 \\
\hline
\end{tabular}

\section{Catatan:}

IFR adalah Internet Financial reporting dan $\mathrm{Q}$ adalah nilai perusahaan

Berdasar Tabel 2, variabel Internet Financial Reporting (IFR) menunjukkan nilai rata-rata sebesar 0,50 dan deviasi standar sebesar 0,50. Nilai minimum penerapan IFR adalah 0,00 dan nilai maksimum adalah 1,00. Rata-rata dan deviasi standar variabel nilai perusahaan $(\mathrm{Q})$ adalah sebesar 2,04 dan 2,06. Nilai minimum untuk $Q$ adalah 0,13 dan maksimumnya adalah 14,04. Deviasi standar variabel Internet Financial Reporting (IFR) dan nilai perusahaan (Q) relatif kecil, hal tersebut menunjukkan bahwa keragaman kelompok data untuk masing-masing variabel kecil sehingga data penelitian layak untuk dilakukan pengujian. Sedangkan statistik deskriptif variabel penelitian ini disajikan dalam tabel 3.

Tingkat pengungkapan informasi website (TPIW) memiliki nilai rata-rata dan deviasi standar sebesar 0,68 dan 0,19. Nilai minimum TPIW adalah 0,20 dan nilai maksimum TPIW adalah 1,00. Variabel lingkup pelaporan internet mempunyai rata-rata sebesar 0,71 dan deviasi standar 0,24 .

Tabel 3

Statistik Deskriptif TPIW, LPI, SIZE, ROA, dan Q

\begin{tabular}{llcccc}
\hline \hline & $\mathbf{N}$ & Minimum & Maximum & Mean & Standard Dev. \\
\hline TPIW & 92 & 0,20 & 1,00 & 0,68 & 0,19 \\
LPI & 92 & 0,25 & 1,00 & 0,71 & 0,24 \\
SIZE & 92 & 23,55 & 32,84 & 28,48 & 1,71 \\
ROA & 92 & $-0,26$ & 0,58 & 0,10 & 0,12 \\
Q & 92 & 1,00 & 13,88 & 2,59 & 2,09 \\
\hline
\end{tabular}

Catatan:

TPIW adalah tingkat pengungkapan informasi website, LPI adalah luas lingkup pengungkapan IFR, SIZE adalah ukuran perusahaan, ROA adalah profitablitas, dan Q adalah nilai perusahaan. 
Nilai minimum untuk LPI sebesar 0,25 dan nilai maksimum LPI adalah 1,00. Variabel ukuran perusahaan menunjukkan rata-rata sebesar 28,48 dan deviasi standar yaitu 1,71. Nilai minimum SIZE adalah 23,55 dan nilai maksimum sebesar 32,84. Variabel profitabilitas mempunyai rata-rata 0,10 dan deviasi standar sebesar 0,12. Nilai minimum ROA adalah $-0,26$ dan nilai maksimum sebesar 0,58 . Nilai perusahaan mempunya rata-rata sebesar 2,59 dan deviasi standar sebesar 2,09. Nilai minimum untuk $Q$ yaitu 1,00, sedangkan nilai maksimumnya adalah 13,88. Deviasi standar variabel penelitian relatif kecil sehingga data penelitian layak dilakukan pengujian.

Selanjutnya penelitian ini dilakukan proses uji normalitas data dan hasil uji normalitas data disajikan dalam tabel 4 berikut ini. Dari hasil Asymp. Sig. (2 tailed) dalam Tabel 4 tampak bahwa data terdistribusi tidak normal, maka dalam uji beda digunakan Uji U-Mann Whitney. Hasil pengujian disajikan dalam tabel 5 .

Hasil pengujian statistik pada Tabel 4 menunjukkan bahwa terdapat perbedaan nilai perusahaan antara perusahaan yang menerapkan IFR dan yang tidak menerapkan IFR. Hasil pengujian statistik pada Tabel 4 menunjukkan bahwa terdapat perbedaan nilai perusahaan antara perusahaan yang menerapkan IFR dan yang tidak menerapkan IFR.

Tabel 4

Hasil Uji Normalitas

\begin{tabular}{llcc}
\hline \hline & & Non IFR & IFR \\
\hline $\mathrm{N}$ & & 92 & 92 \\
Normal Parameter & Mean & 1,49 & 2,59 \\
& Std. Deviation & 1,89 & 2,09 \\
Most Extreme Differences & Absolute & 0,29 & 0,24 \\
& Positive & 0,29 & 0,24 \\
& Negative & $-0,24$ & $-0,22$ \\
Kolmogorov-Smirnov Z & & 2,77 & 2,31 \\
Asymp. Sig. (2-tailed) & & 0,00 & 0,00 \\
\hline
\end{tabular}

Tabel 5

Hasil Uji U-Mann Whitney

\begin{tabular}{|c|c|c|c|c|}
\hline & IFR & $\mathbf{N}$ & Mean Ranks & Sum of Rank \\
\hline \multirow[t]{3}{*}{ Nilai Perusahaan } & 0 & 92 & 64,20 & 5906,50 \\
\hline & 1 & 92 & 120,80 & 11113,50 \\
\hline & Total & 184 & & \\
\hline Asymp. Sig. (2-tailed) & \multicolumn{2}{|c|}{0,000} & & \\
\hline
\end{tabular}

Ini berarti IFR merupakan sebuah solusi yang efektif bagi perusahaan untuk menyediakan lebih banyak informasi dengan tingkat transparansi dan relevansi yang tinggi. Setiap informasi yang disediakan menjadi salah satu sinyal positif bagi investor untuk membuat keputusan yang lebih baik untuk berinvestasi ke perusahaan (Afifurrahman dan Hapsoro, 2005). Kuantitas, transparansi, dan fleksibilitas informasi mengenai peluang investasi perusahaan tersebut akan memberi sinyal positif ten- 
tang pertumbuhan perusahaan di masa yang akan datang, sehingga dapat meningkatkan nilai perusahaan. Hasil ini mendukung penelitian yang dilakukan di Amerika Latin oleh Mendes et al. (2004), di Indonesia oleh Afifurrahman dan Hapsoro (2005), dan di Taiwan oleh Lai et al. (2010). Hal ini membuktikan bahwa penggunaan internet oleh perusahaan di negara berkembang semakin meningkat dari tahun ke tahun dan memberi hasil yang baik berupa tingginya nilai perusahaan, sehingga kondisi tersebut menyebabkan perusahaan dapat lebih bersaing dalam perdagangan global yang semakin luas.

Selanjutnya hasil analisis pengujian setiap variabel penelitian yaitu tingkat pengungkapan informasi website (TPIW), luas lingkup pengungkapan IFR (LPI), ukuran perusahaan (SIZE), profitablitas (ROA), dan nilai perusahaan (Q) disajikan dalam tabel 5 berikut ini.

Tabel 5

Hasil Analisis Regresi Linier Berganda

\begin{tabular}{lccc}
\hline \multicolumn{1}{c}{ Model } & Koefisien & T & Sig.t \\
\hline Konstanta & 6,26 & 2,24 & 0,28 \\
TPIW & 3,59 & 3,84 & 0,00 \\
LPI & 1,60 & 2,20 & 0,03 \\
SIZE & $-0,28$ & $-2,81$ & 0,01 \\
ROA & 8,13 & 5,53 & 0,00 \\
\hline R & $=0,68$ & & \\
R2 & $=0,46$ & & \\
F & $=18,33$ & & \\
Sig. F & $=0,00$ & \\
\hline \multicolumn{4}{l}{ Variabel Terikat : Nilai Perusahaan $(\mathrm{Q})$} \\
\hline
\end{tabular}

Hasil statistik pada Tabel 5 menunjukkan bahwa tingkat pengungkapan informasi website dengan koefisien 3,59 dan nilai $\mathrm{t} 3,84$ signifikan pada level 1 persen. Demikian pula variabel lingkup pelaporan internet memiliki koefisien 1,60, nilai t sebesar 2,20 signifikan pada level 5\%. Ini berarti kedua variabel tersebut berpengaruh signifikan terhadap nilai perusahaan. TPIW dan LPI merupakan derajat atau kuantitas dari pengungkapan informasi perusahaan melalui internet yang salah satunya adalah informasi keuangan. Objek dari tingkat pengungkapan informasi website dan lingkup pelaporan internet adalah konten atau isi dan link penghubung yang ada dalam sebuah website perusahaan. Apabila tingkat atau derajat transparansi ini mencapai tingkat yang tinggi, maka stakeholder terutama investor akan mendapat informasi yang lebih relevan, tepat waktu, bahkan lebih awal mengenai perusahaan dan kemudian dapat mempengaruhi keputusan investor mengenai prospek perusahaan di masa depan. Hasil ini mendukung penelitian yang dilakukan Lai et al. (2010) serta Nurunnabi dan Hossain (2012).

Variabel kontrol yang digunakan dalam penelitian ini yaitu ukuran perusahaan dan profitabilitas, dan hasil pengujian menunjukkan bahwa ukuran perusahaan berpengaruh negatif signifikan terhadap nilai perusahaan. Hasil penelitian ini mendukung temuan penelitian sebelumnya (Afifurrahman dan Hapsoro, 2005; Harjito, 2006; Siallagan dan Machfoedz, 2006). Semakin besar perusahaan akan diikuti dengan semakin besar pula risiko yang dihadapi perusahaan. Beberapa hal ini dapat menimbulkan berbagai masalah serius bagi perusahaan, salah satunya adalah rentan terjadinya asimetri informasi, sehingga tiap perusahaan wajib mempunyai cara yang lebih efektif dan efisien untuk mengelola 
perusahaannya. Penelitian ini membuktikan bahwa tidak semua perusahaan besar mampu mengelola nilai perusahaannya dengan efektif dan efisien.

Profitabilitas perusahaan mempunyai pengaruh positif signifikan terhadap nilai perusahaan. Hasil ini konsisten dengan penelitian Aly et al. (2010) dan Lai et al. (2010). Perusahaan-perusahaan dengan tingkat profitabilitas yang baik akan memiliki dorongan yang lebih kuat untuk menyebarluaskan informasi mengenai perusahaannya, terutama informasi keuangan, karena profitabilitas yang tinggi merupakan salah satu indikasi bahwa perusahaan tersebut telah mencapai kinerja dengan baik.

\section{SIMPULAN DAN SARAN Simpulan}

Dari temuan riset ini, dapat ditarik simpulan bahwa IFR mempengaruhi nilai perusahaan. Perusahaan yang menerapkan Internet Financial Reporting memiliki nilai perusahaan lebih besar dibandingkan dengan perusahaan yang tidak menerapkan Internet Financial Reporting.

Tingkat pengungkapan informasi website (TPIW) dan lingkup pelaporan internet (LPI) juga menunjukkan pengaruh positif terhadap nilai perusahaan. Dengan demikian dua elemen penting IFR yaitu semakin tinggi tingkat pengungkapan informasi website dan lingkup pelaporan internet terbukti dapat meningkatkan nilai perusahaan. Ukuran perusahaan berpengaruh negatif dan signifikan terhadap nilai perusahaan sedangkan profitabilitas perusahaan berpengaruh positif dan signifikan terhadap nilai perusahaan.

\section{Saran}

Implikasi dari hasil penelitian ini adalah bahwa penggunaan internet pada saat ini dan masa-masa yang akan datang adalah bukan sebuah keniscayaan. Investasi pada bidang ini adalah sebagai upaya untuk meningkatkan tanggungjawab perusahaan dan perlu mendapat perhatian serius. Di samping itu, kehadiran teknologi informasi akan memberi keuntungan ganda. Pertama akan meningkatkan efisiensi biaya dan juga efisiensi operasi. Kedua, teknologi informasi berperan sebagai enabler, yang memampukan perusahaan meningkatkan posisi strategis.

Penyajian informasi dalam format Internet Financial Reporting menjadi semakin penting bagi perusahaan kecil, mengingat aksesibilitas publik terhadap perusahaanperusahaan kecil relatif lebih terbatas dibandingkan dengan perusahaan besar.

\section{DAFTAR PUSTAKA}

Abdelsalam, O., S. Bryant, dan D. Street. 2007. An Examination of the Comprehensiveness Corporate Internet Reporting Provided by London Listed Companies. Journal of International Accounting Research 6(2): 1-33.

Afifurrahman, W. dan D. Hapsoro. 2005. Pengaruh Pengungkapan Sukarela melalui Website terhadap Nilai Perusahaan pada Perusahaan yang Terdaftar di Bursa Efek Jakarta. Jurnal Akuntansi dan Manajemen 19(1): 1-14.

Almilia, L. S. 2009. Analisa Komparasi Indeks Internet Financial Reporting pada Website Perusahaan Go Publik di Indonesia. Paper presented at the Seminar Nasional Aplikasi Teknologi Informasi, Yogyakarta.

Aly, D., J. Simon, dan K. Hussainey. 2010. Determinants of corporate Internet Reporting: Evidence from Egypt. Managerial Auditing Journal 25(2): 182202.

Ashbaugh, H., K. M. Johnstone, dan T. D. Warfield. 1999. Corporate Reporting on the Internet. Accounting Horizons 13(3): 241-257.

Barac, K. 2004. Financial reporting on the internet in South Africa. Meditari Accountancy Research 12(1): 1-20.

Craven, B. M. dan C. L. Marston. 1999. Financial Reporting on the Internet by 
Leading UK Companies. The European Accounting Review1 8(2): 321-333.

Dalton, D. R., M. A. Hitt, dan S. T. Certo. 2007. The Fundamental Agency Problem and Its Litigation: Independence, Equity and the Market for Corporate Control. Academy of Management Annals 1: 1-64.

Damayanti, K. dan Supatmi. 2012. Internet Financial Reporting (IFR) dan Reaksi Pasar. Proceeding: Pekan Ilmiah Dosen FEB Universitas Kristen Satya Wacana: 613-626.

Debreceny, R., G. L. Gray, dan A. Rahman. 2002. The Determinants of Internet Financial Reporting. Journal of Accounting and Public Policy 21:371-394.

Easley, D., S. Hvidkjaer, dan M. O'Hara. 2002. Is Information Risk a Determinant of Asset Returns Journal of Finance 7(5).

Ettredge, M., V. J. Richardson, dan S. Scholz. 2002. Determinants of Voluntary Dissemination of Financial Data At Corporate Web Sites.Paper presented at the Hawaii International Conference on System Sciences, Hawaii.

Fama, E. F. 1978. The Effects of a Firm's Investment and Financing Decisions on the Welfare of Its Security Holders. The American Economic Review: 272-284.

Fassin, Y. 2009. The Stakeholder Model Refined. Journal of Business Ethics D/7012/13.

Harjito, D. A. 2006. Substitution Relationship Between The Agency Problem Control Mechanisms in Malaysia: Simultaneous Equation Analysis. Siasat Bisnis 11(2): 117-127.

Lai, S. C., C. Lin, H. Li, dan F. H. Wu. 2010. An Empirical Study of the Impact of Internet Financial Reporting on Stock Prices. The International Journal of Digital Accounting Research 10: 1-26.

Lestari, H. S. dan A. Chariri. 2005. Analisis Faktor-Faktor yang Mempengaruhi Pelaporan Keuangan melalui Internet (Internet Financial Reporting) dalam Website Perusahaan. Unpublished Thesis.
Fakultas Ekonomi Universitas Diponegoro.

Masykur, I. 2013. Faktor-Faktor yang Mempengaruhi Pengungkapan Kinerja Perusahaan di Website. Skripsi. Fakultas Ekonomi dan Bisnis Universitas Hasanuddin Makassar.

Mendes, D. S., A. Luiz, dan D. L. Alves. 2004. The Voluntary Disclosure of Financial Information on the Internet and the Firm Value Effect in Companies Across Latin America.

Mooduto, W. I. S. 2013. Reaksi Investor atas Pengungkapan Internet Financial Reporting. Jurnal Reviu Akuntansi dan Keuangan 3(2): 479-492.

Nurlela, R. dan Islahuddin. 2008. Pengaruh Corporate Social Responsibility Terhadap Nilai Perusahaan dengan Prosentase Kepemilikan Manajemen Sebagai Variabel Moderating. Paper presented at the Simposium Nasional Akuntansi XI, Pontianak.

Nurunnabi, M. dan M. A. Hossain. 2012. The Voluntary Disclosure of Internet Financial Reporting (IFR) in an Emerging Economy: A Case of Digital Bangladesh. Journal of Asia Business Studies 6(1): 17-42.

Oyelere, P. dan N. Kuruppu. 2012. Voluntary Internet Financial Reporting Practices of Listed Companies in the United Arab Emirates. Journal of Applied Accounting Research 13(3): 298-315.

Prasetya, M. dan S. A. Irwandi. 2012. Faktor-Faktor yang Mempengaruhi Pelaporan Keuangan melalui Internet (Internet Financial Reporting) pada Perusahaan Manufaktur di Bursa Efek Indonesia. The Indonesian Accounting Review 2(2): Juli.

Salvatore, D. 2005. Managerial Economic: Ekonomi Manajerial dalam Perekonomian Global (Kelima ed.). Jakarta: Salemba Empat.

Siallagan, H. dan M. Machfoedz. 2006. Mekanisme Corporate Governance, Kualitas Laba, dan Nilai Perusahaan. 
Paper presented at the Simposium Nasional Akuntansi IX, Andalas, Padang.

Srimindarti, C. 2008. Ketepatan Waktu Pelaporan Keuangan. Fokus Ekonomi 7(1): 14-21.

Sugiyono. 2008. Metode Penelitian Bisnis. Penerbit Alfabeta, Bandung

Sukamulja dan Sukmawati. 2004. Good Corporate Governance di Sektor Keuangan: Dampak Good Corporate
Governance terhadap Kinerja Perusahaan (Kasus di Bursa Efek Jakarta). Benefit 8(1).

Wolk, H. I., M. G. Tearney dan J. L. Dodd. 2001. Accounting Theory: A Conceptual and Institutional Approach. 5th Edition, Cincinnati, Ohio, South-Westrn College Publishing. 